\author{
اثر شورى آب آبيارى و كود دامى بر آبشويى باكترى اشرشياكلى آزاد \\ در ستونهاى خاى دستخورده \\ حسين شيرانى '، سميه شيروانى' و محمد مرادى

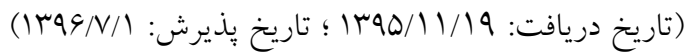

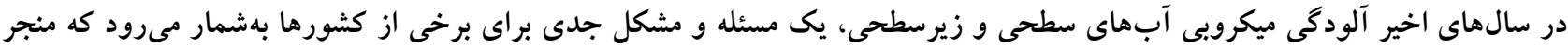

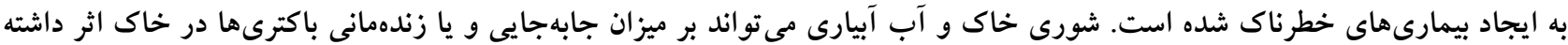

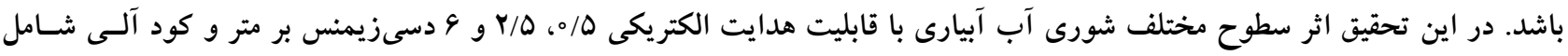

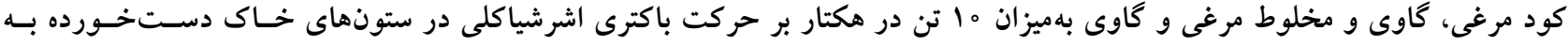

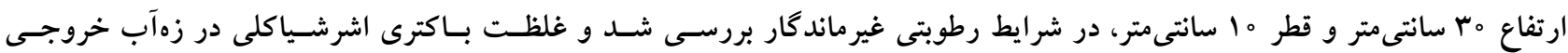

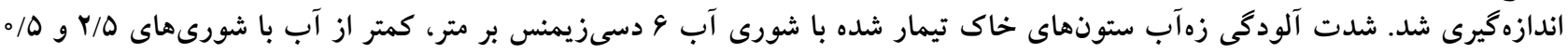

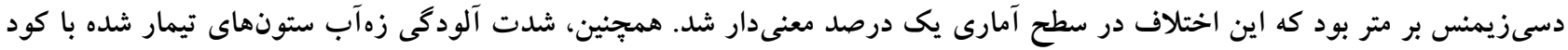

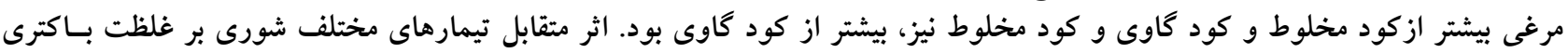

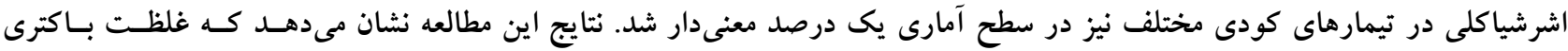

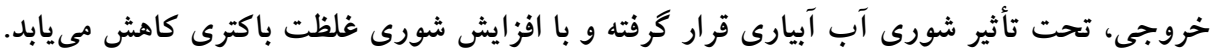

وازههاى كليدى: منحنى رخنه، كود مرغى، كود گاوى، زهآب خروجى

ا. بر كروه علوم خاك، دانشكده كشاورزى، دانشخاه ولى عصر (عج) رفسنجان

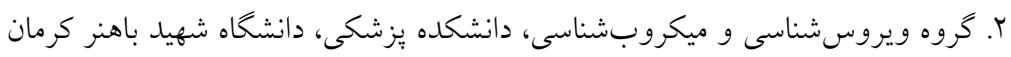

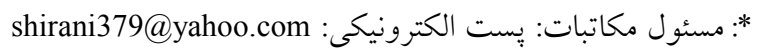


ه ما روز در دماى م ا درجه سانتى گـر اد بـاقى مسىمانـد. نتسايج

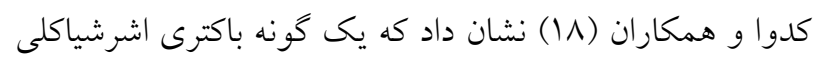

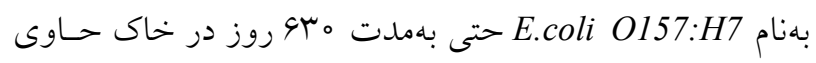

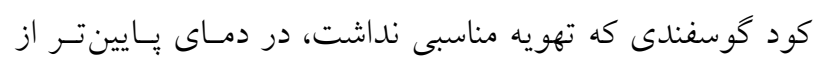

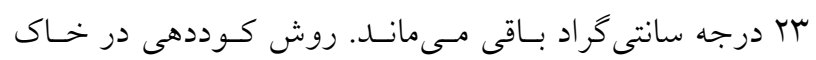

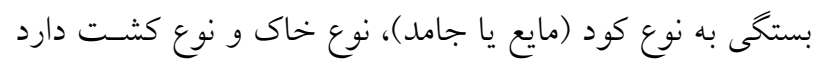

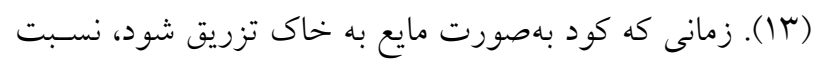

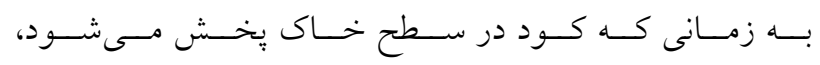

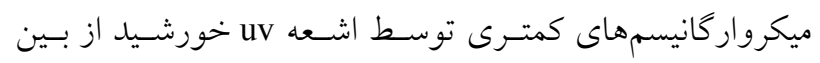

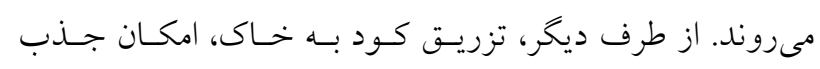

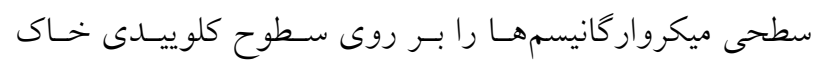

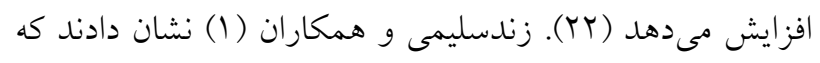

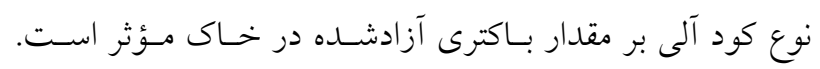

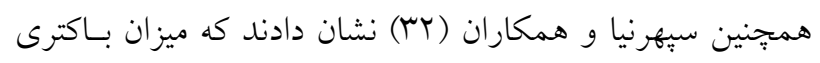

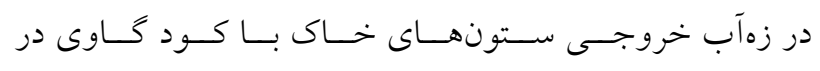

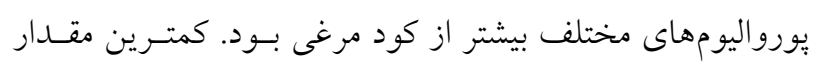

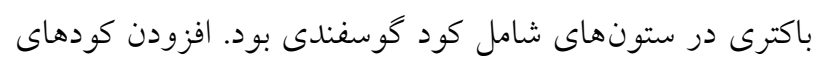

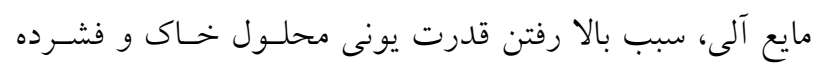

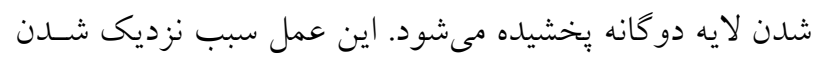

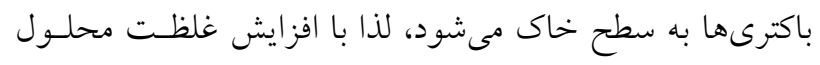

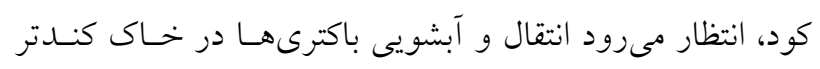

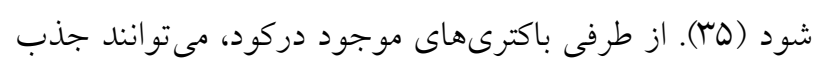

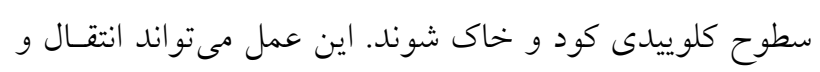

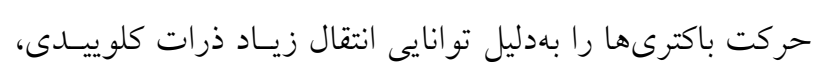

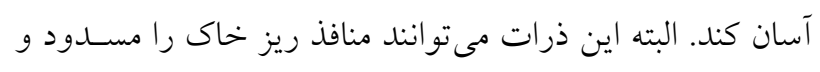

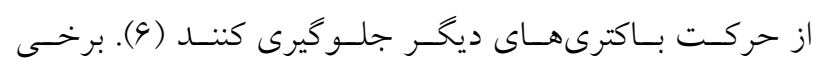

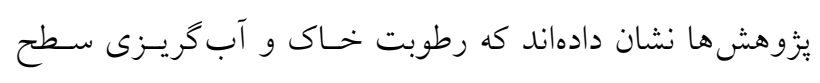

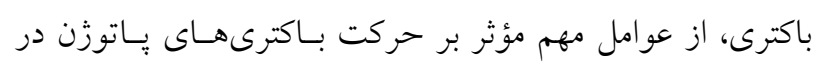

خاى هستند (1) - (I).

عمق انتقال باكترىها در خاكهاى مختلف متفـاوت استـت.

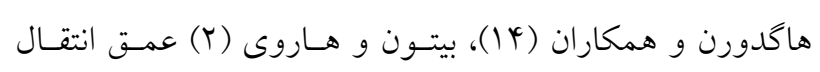

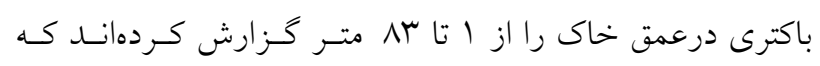

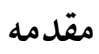

باكترىها بهدليل تنوع متابوليكى، قادرند در جاهايى زندكى كنند

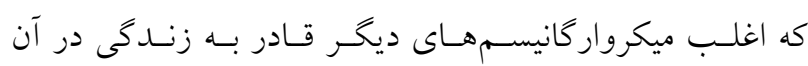

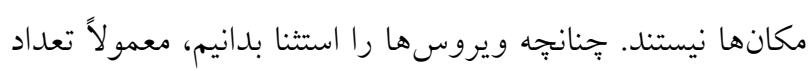

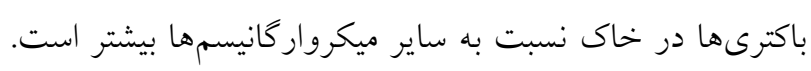

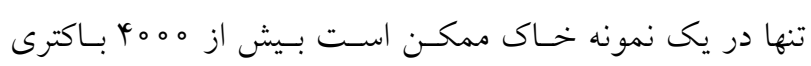

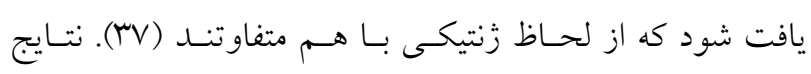

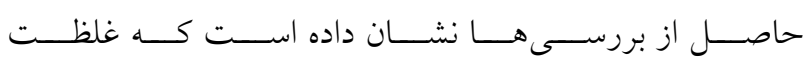

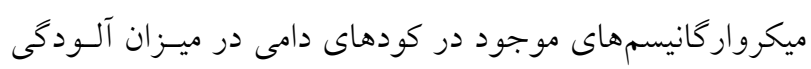

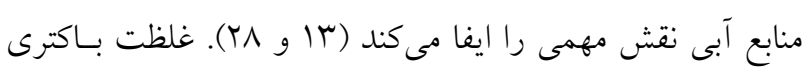

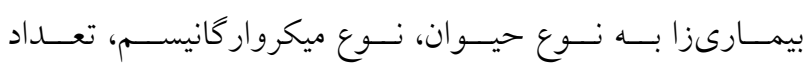

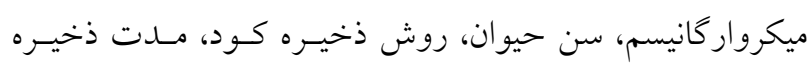

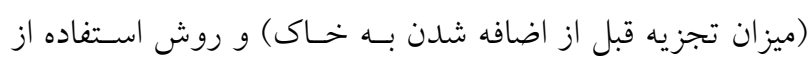

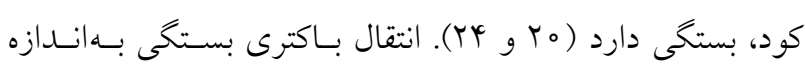

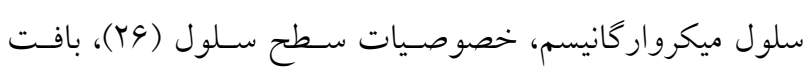

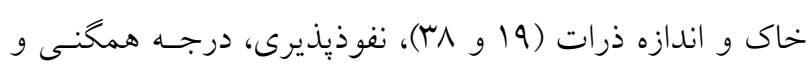

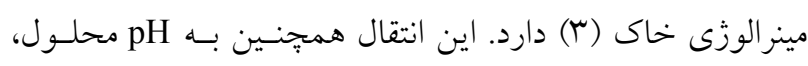

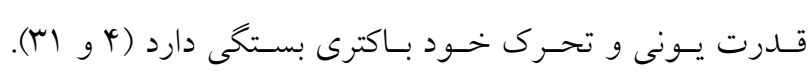

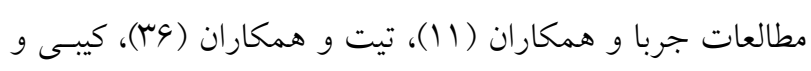

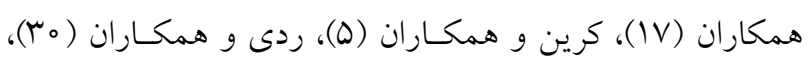

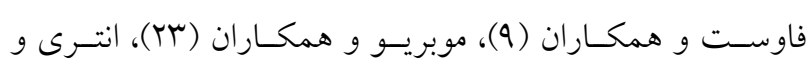

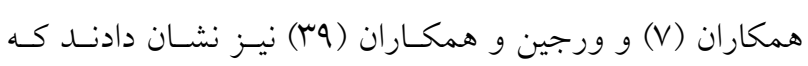

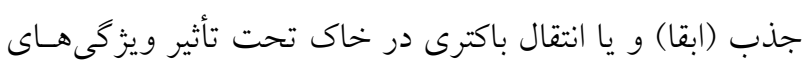

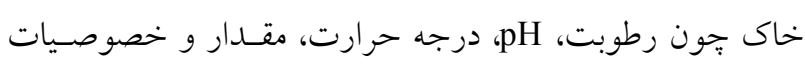

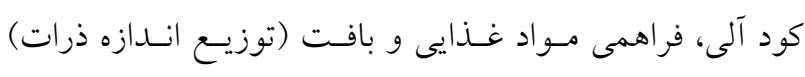

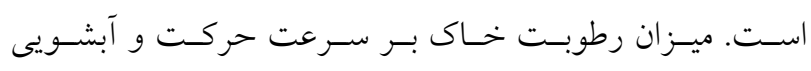

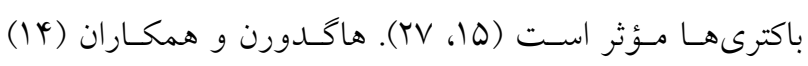

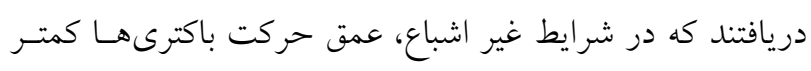

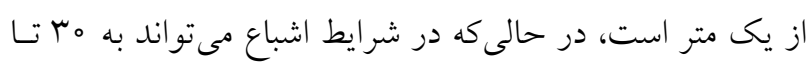

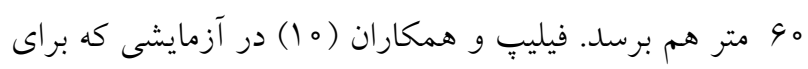
تعيين قابليت بقاى جند ميكروار كانيسم در خـاك اشـباع انجـام

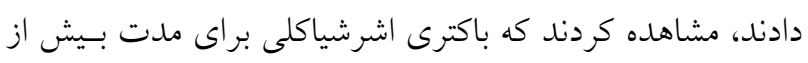




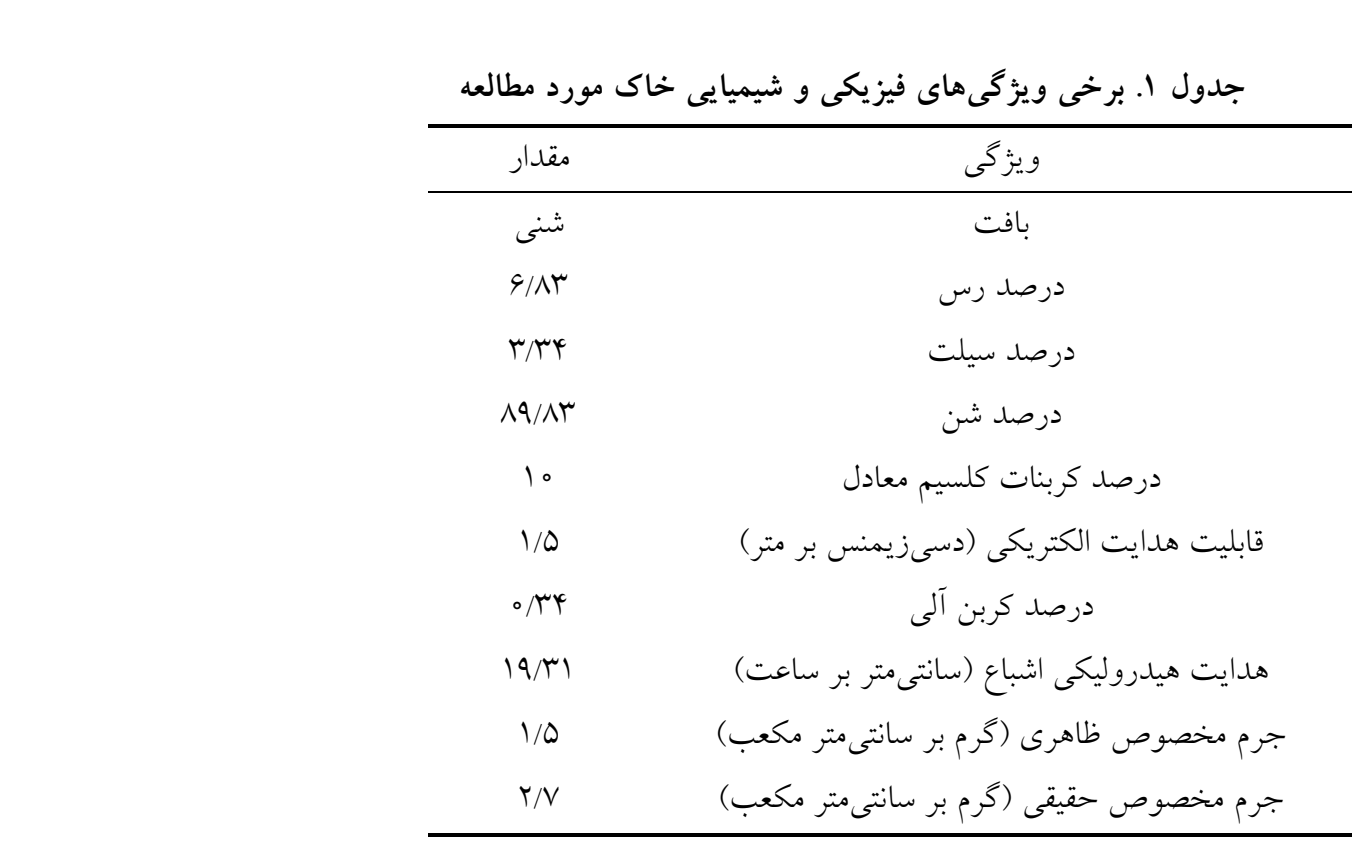

ولى عصر (عج) رفسنجان بـا بافـت شـنى تهيـهـ شـــ. برخـى از

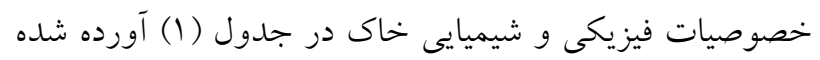

$$
\text { است. }
$$
كود مرغى مورد استفاده از مرغهاى خانكى و كود كاوى نيز

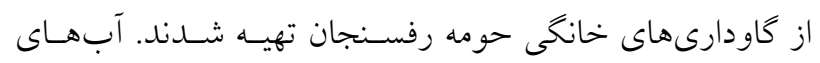

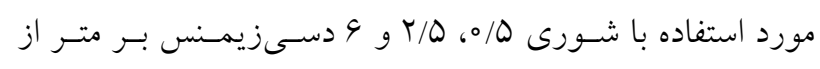

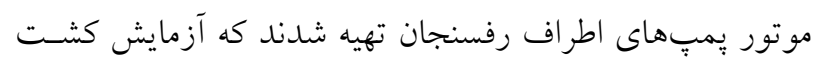

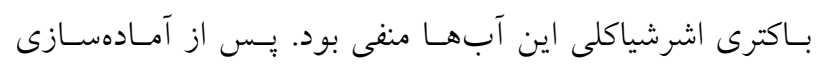

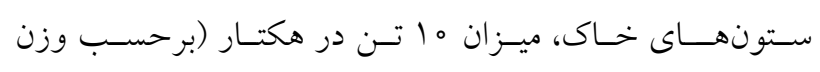

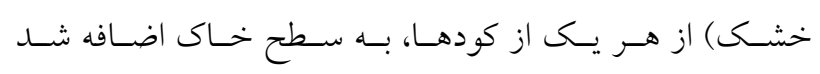

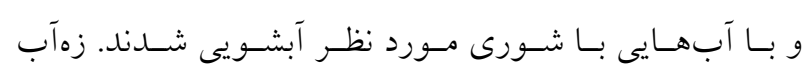

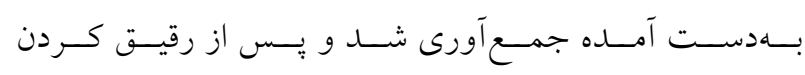

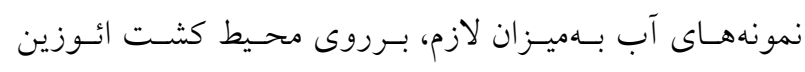

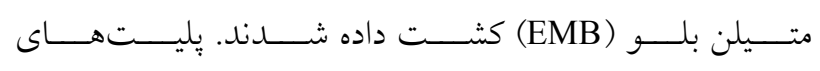

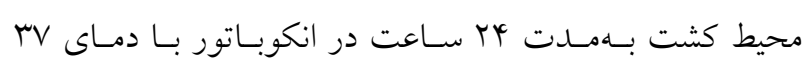

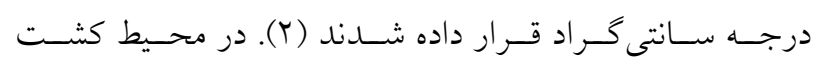

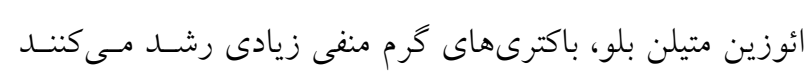

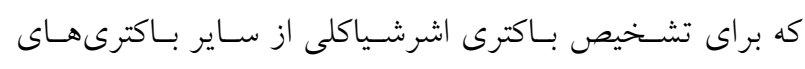

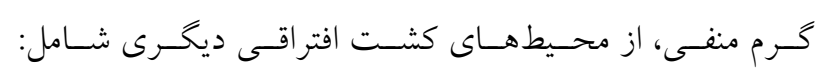
،(SH2 indole motility) SIM ،(Triple Sugar Iron Agar) TSI

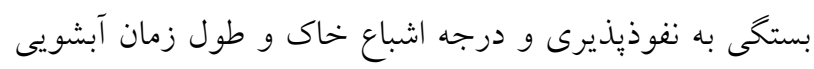

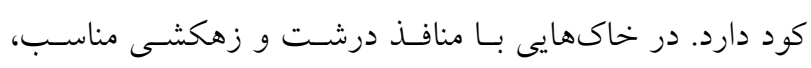

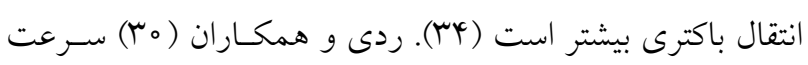

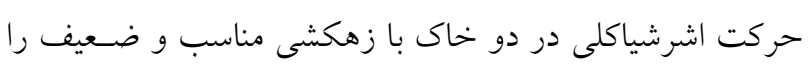

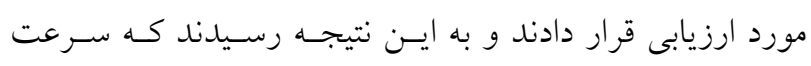
حركت باكترى اشرشياكلى در خاك با زهكشى مناسب بيشتر از

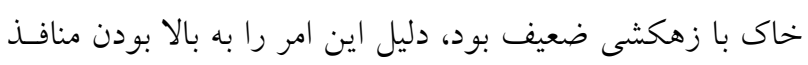
درشت در خاك با زهكشى مناسب نسبت دادند.

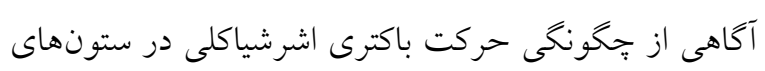

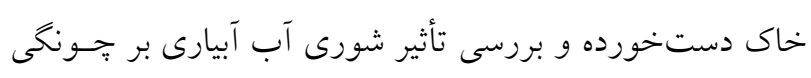

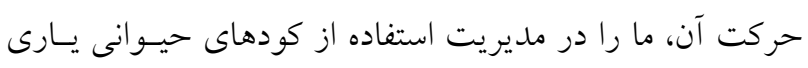

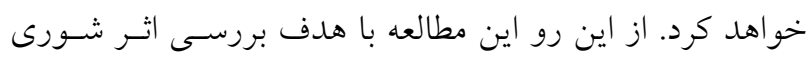

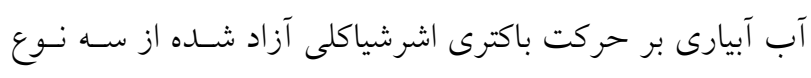
كود در خاى دستخورده، انجام كرفت.

\section{مواد و روشها}

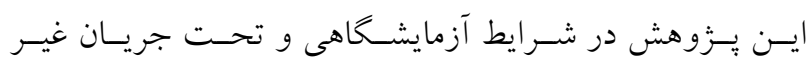

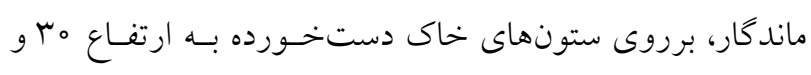

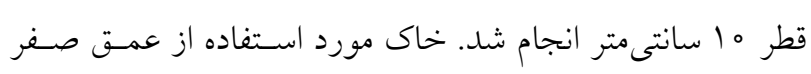

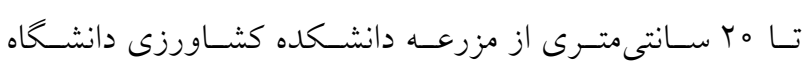


نوع كود مرغسى، كَاوى و مخلـوط در ابتـداى آبشـويى تقريبـاً

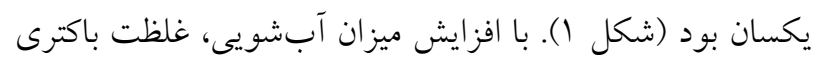

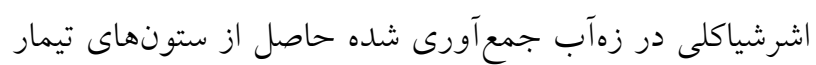
شده با كود كاوى، كاهش يافت.

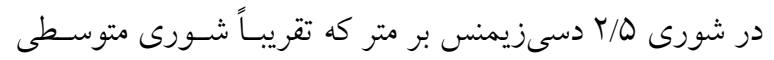

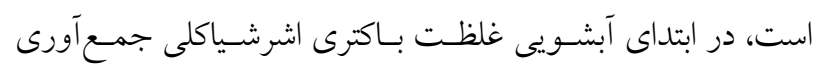

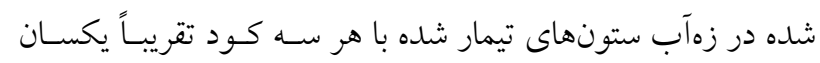

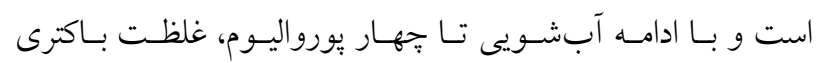

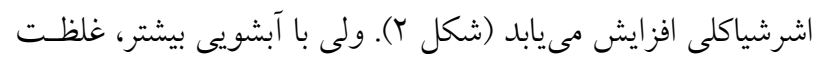
باكترى اشرشياكلى در زهآب كود گاوى كاهش يافته، تا جايى كـه از

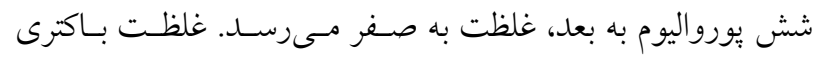

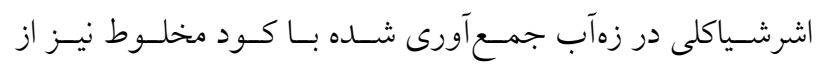

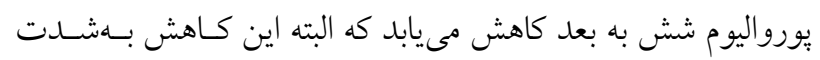

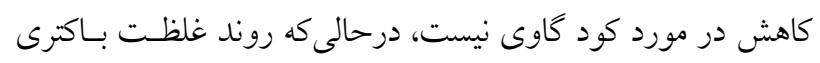
اشرشياكلى در كود مرغى ثابت و يكنواخت است.

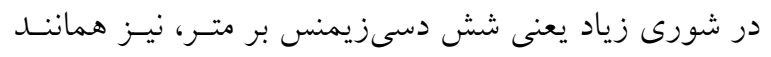

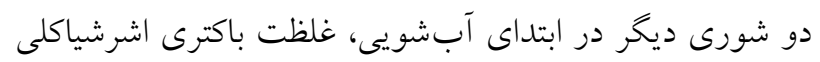

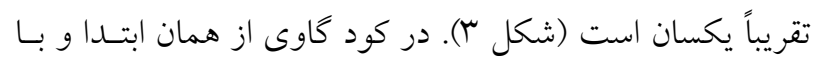

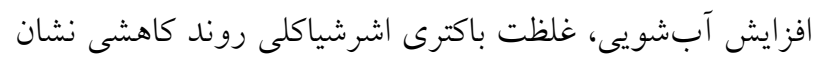

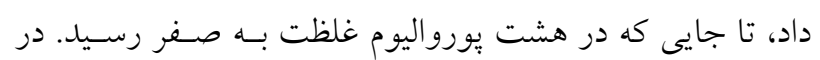

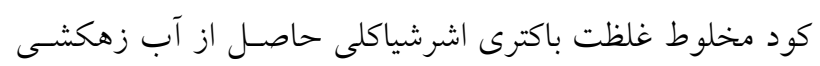

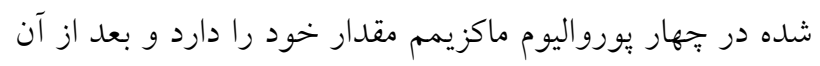
غلظت بهسرعت كاهش مى يابد تـا جـايى كـه در ه إيورواليـوم

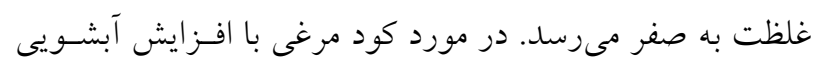

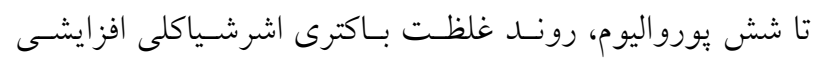

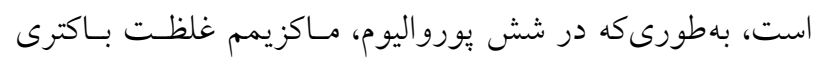

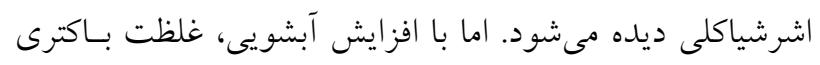
اشرشياكلى در اين كود نيز كاهش جشمخيرى بيدا مي كند.

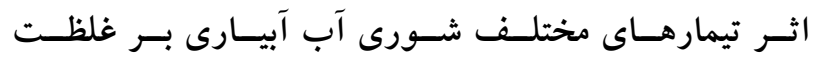

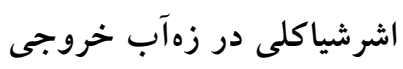
اثر تيمارهاى شورى مختلف بر غلظـت بـاكترى اشرشـياكلى در درو
(Methyl red - Voges Proskauer) MR-VP استفاده شد (Yq). تعداد كلونى رشد كرده بر روى محيط كشت،

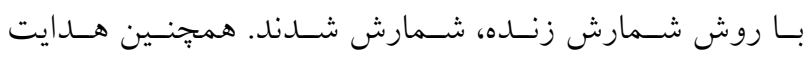
الكتريكى زهآب خروجى نيز اندازهكيرى شد.

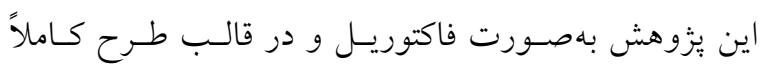

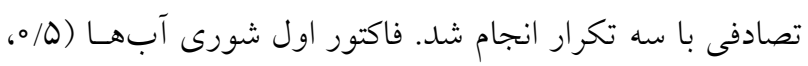

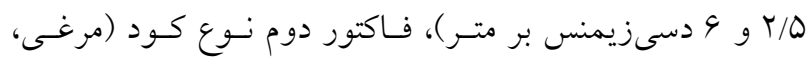

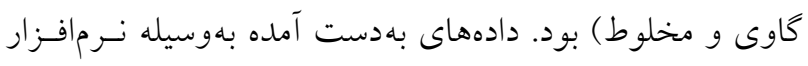

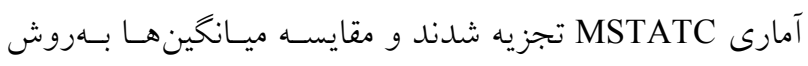

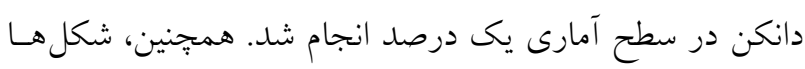

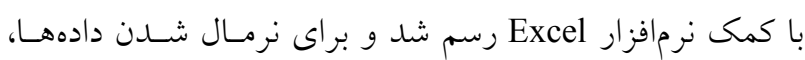

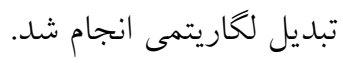

\section{نتايج و بحث} اثر تيمارهاى كود بر منحنى رخنسه بـاكترى اشرشـياكلى در شورىهاى مختلف

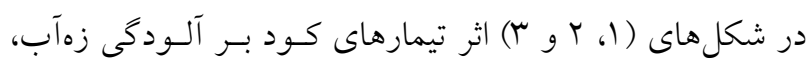

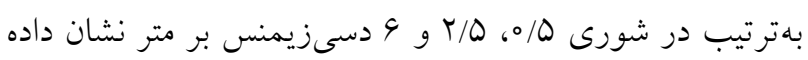

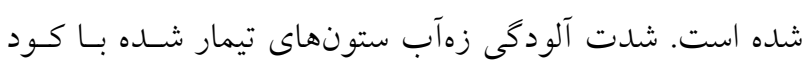
مرغى بيشتر از كودهاى مخلوط و كاوى بود كه دليل آن احتمالاً

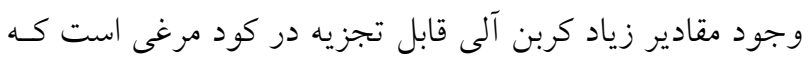

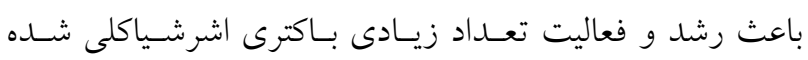

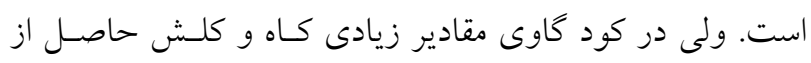

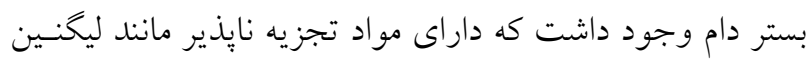

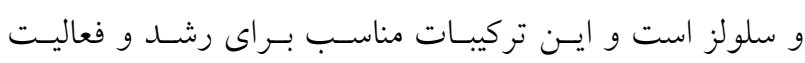

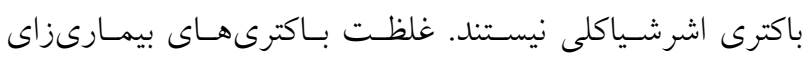

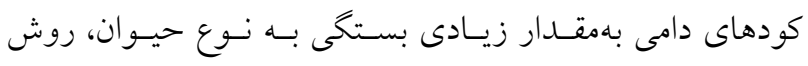

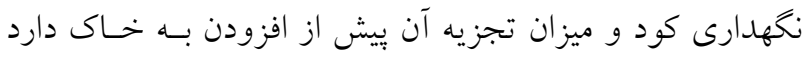

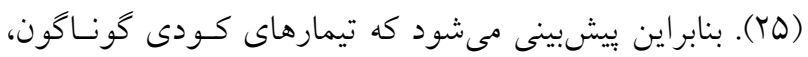

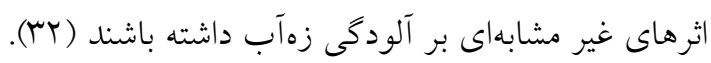

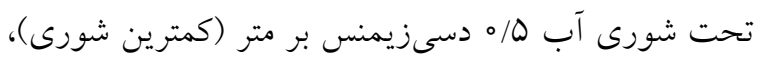

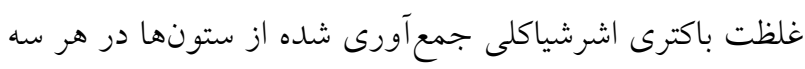




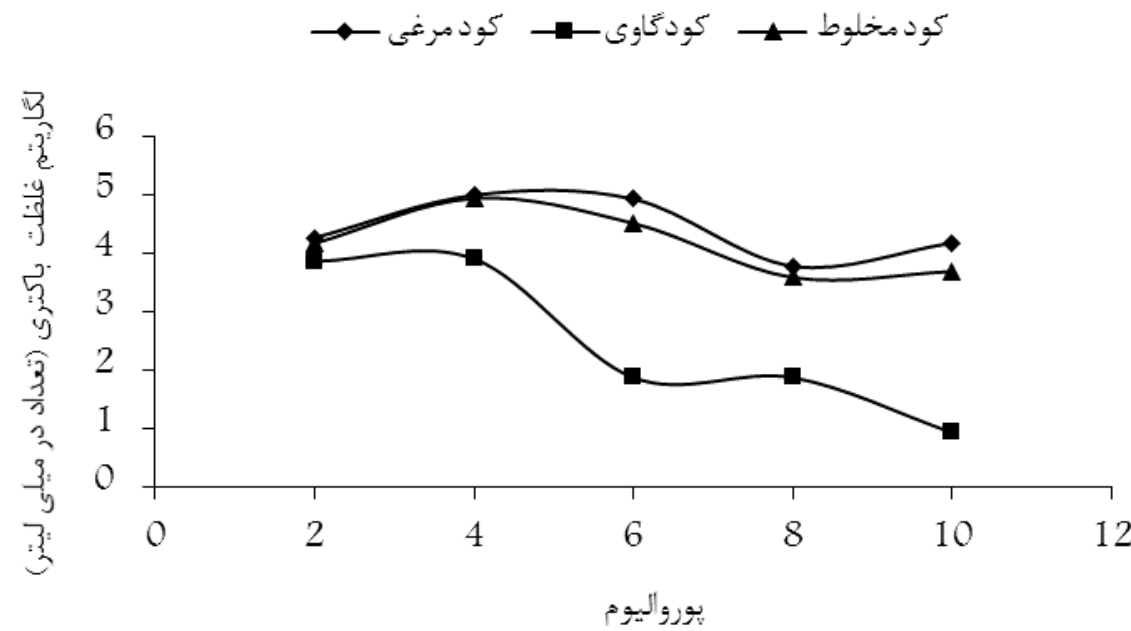

شكل ا. منحنى رخنه باكترى اشرشياكلى در شورى ه/ه دسىزيمنس بر متر

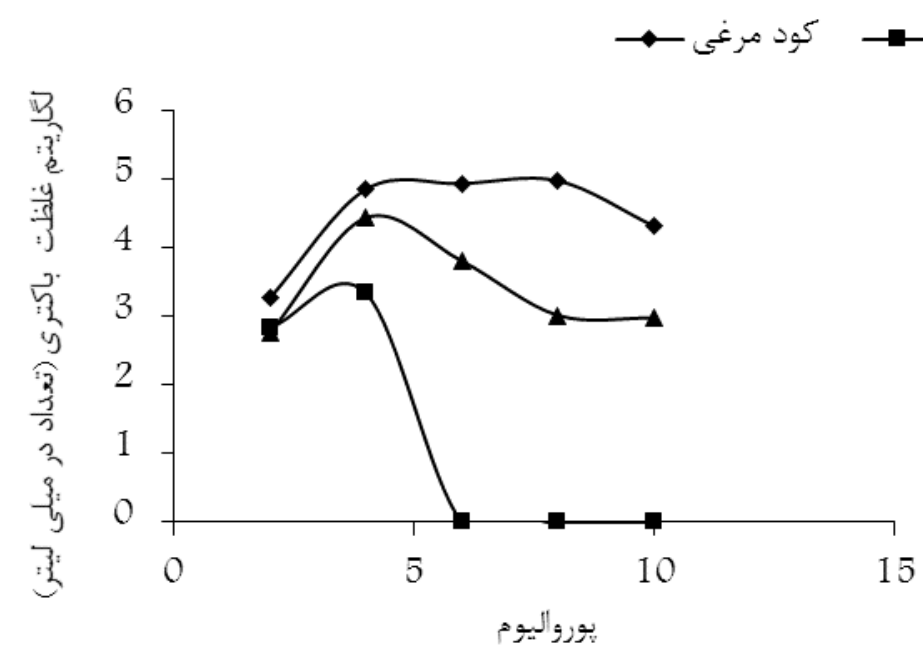

شكل Y. منحنى رخنه باكترى اشرشياكلى در شورى Y/ه دسىزيمنس بر متر

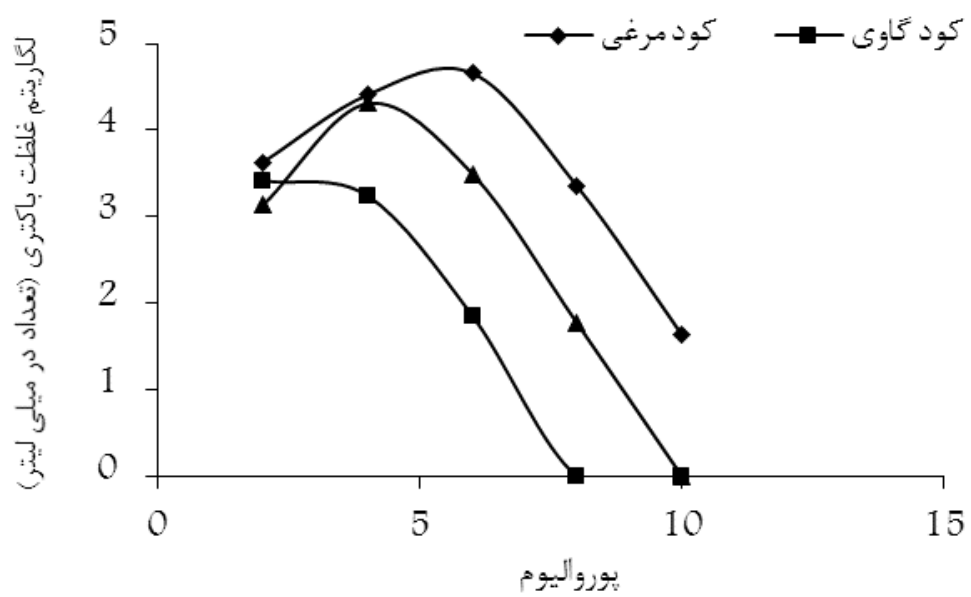

شكل ؟. منحنى رخنه باكترى اشرشياكلى در شورى 9 دسىزيمنس بر متر 


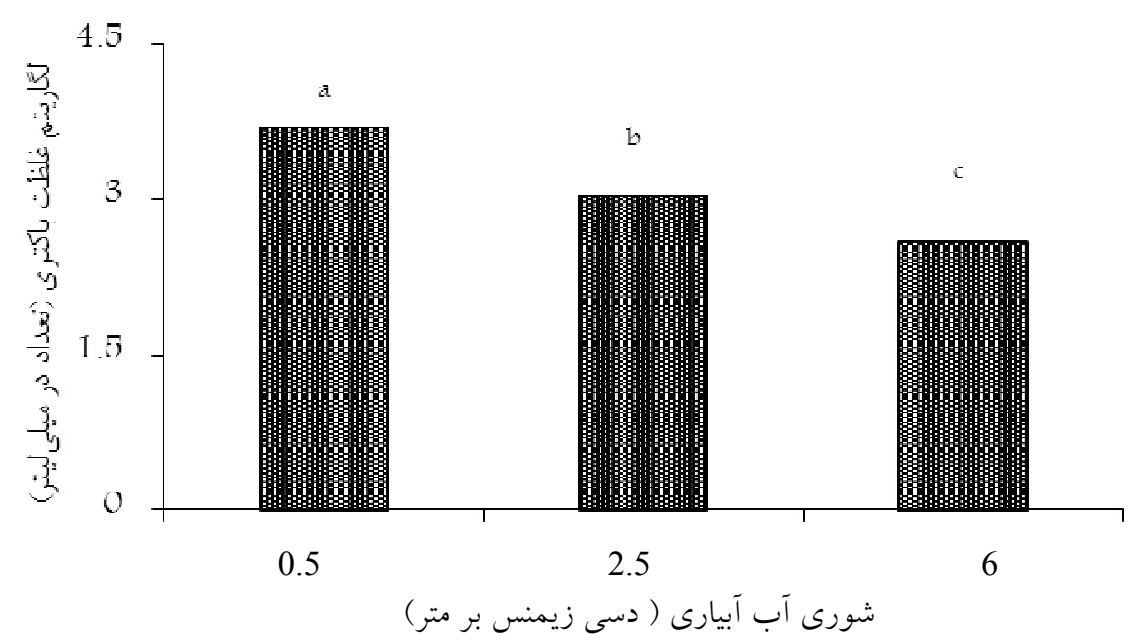

شكل f. اثر شورىهاى مختلف بر غلظت اشرشياكلى. حروف مشابه بيانگر نبود اختلاف معنىدار در سطح احتمال بنج درصد است

جدول r. نتايج تجزيه واريانس تأثير شورى آب آبيارى و نوع كود دامى بر غلظت باكترى زهآب خروجى

\begin{tabular}{|c|c|c|c|}
\hline $\mathrm{F}$ & ميانخين مربعات & درجه آزادى & منابع تغيير \\
\hline$M T / \circ \Delta Q V^{* *}$ & $117 / 9 V 9$ & r & شورى \\
\hline 100/RTG & GY/ANY & r & كود دامى \\
\hline$V / 9 \circ 9 \mu^{* *}$ & $r / \mid F V$ & $r$ & شورى × كود دامى \\
\hline
\end{tabular}

رفتن قدرت يونى محلول خاك و فشرده شدن لايه دو گانـهـ بِخشـيده

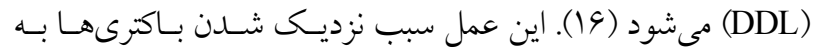

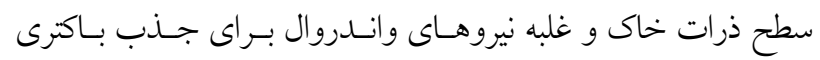
روى سطح ذرات خاك مىشود، لذا با افزايش غلظت محلول، انتفـال و آبشويى باكترىها در خاك كاهش مىيابد (II).

اثر تيمارهاى كودى بر غلظت باكترى اشرشسياكلى در زهآب خروجى اثر تيمارهاى كود بر غلظت بـاكترى اشرشسياكلى در شكل

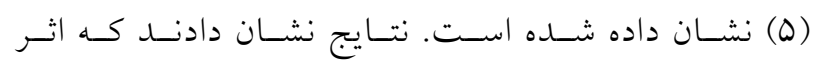
تيمارهاى مختلف كودى بر غلظت بـاكترى اشرشياكلى در

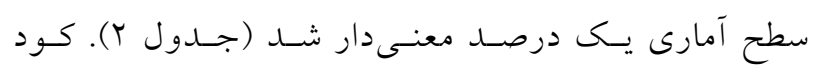

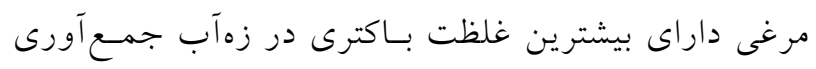

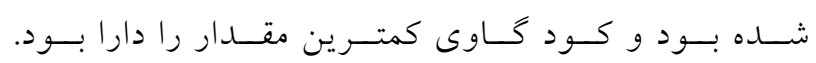

شكل (Y) آورده شده است. نتـايج نشـان دادنـــ كـه تيمارهـاى مختلف شورى بر غلظت باكترى در سطح آمـارى يـك درصــ

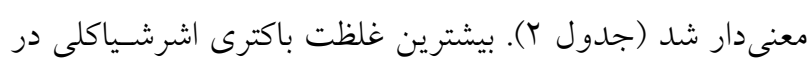

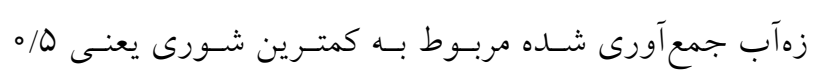

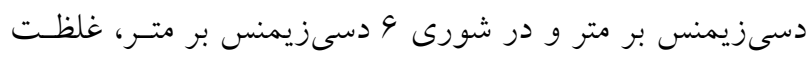

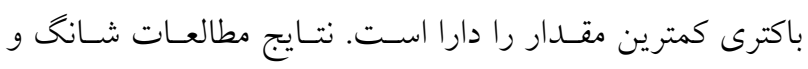

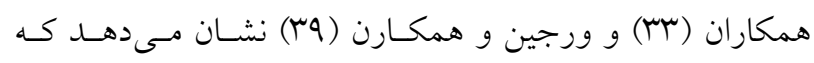

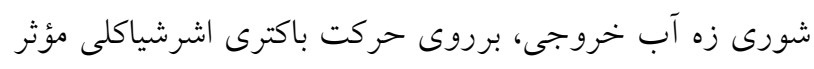

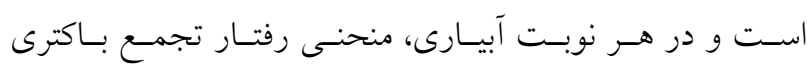

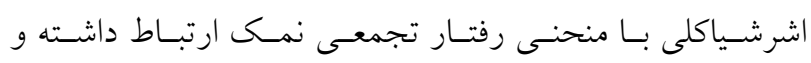

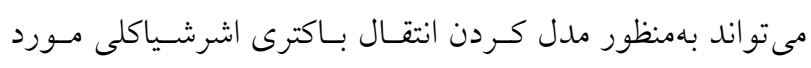
استفاده قرار كيرد. شورى زياد اثر منفى بر غلظت باكترى اشرشـياكلى دارد و باعـث

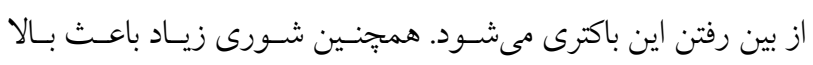




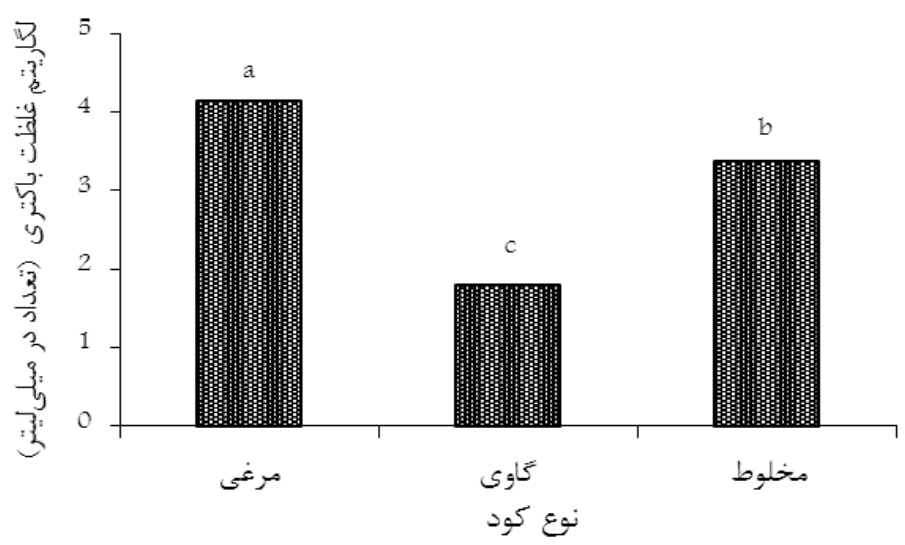

شكل ه. اثر تيمارهاى كودى بر غلظت باكترى اشرشياكلى در زهآب خروجى. حروف مشابه بيانكر نبود اختلاف معنىدار در سطح احتمال ينج درصد است

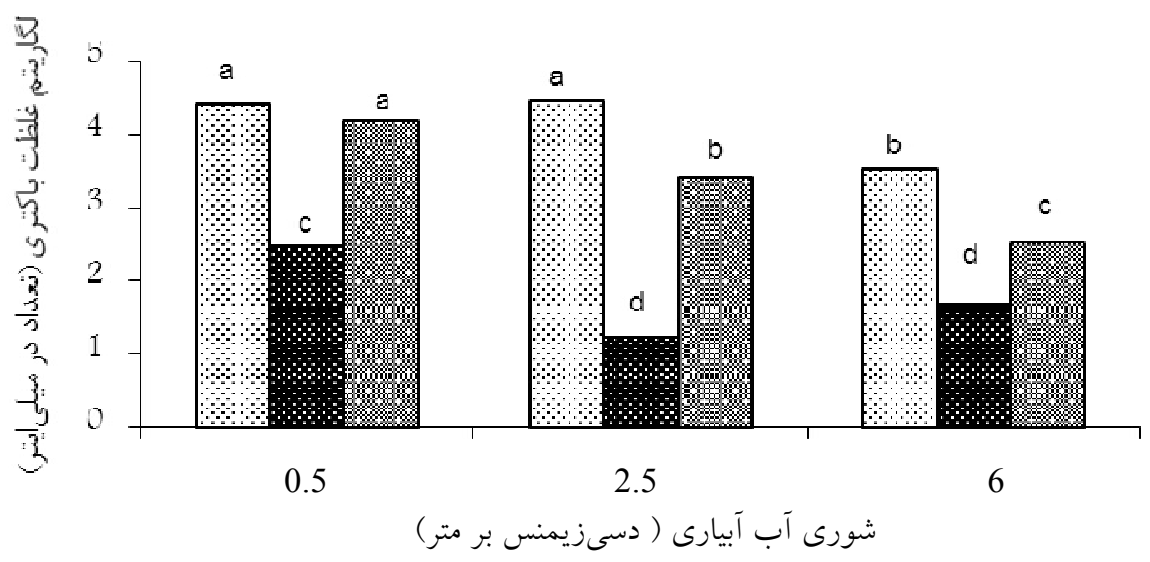

شكل و. اثر متقابل شورىهاى مختلف آب آبيارى و كود بر غلظت باكترى اشرشياكلى در زهآب خروجى. حروف مشابه بيانكر

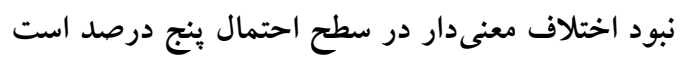

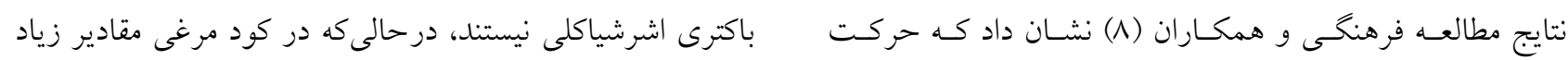

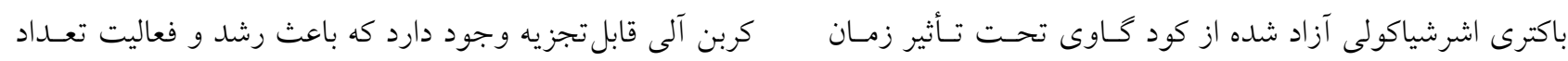

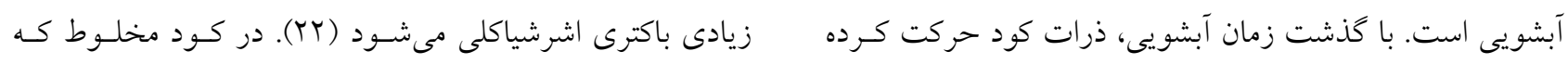

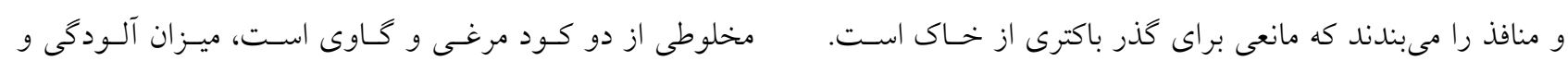

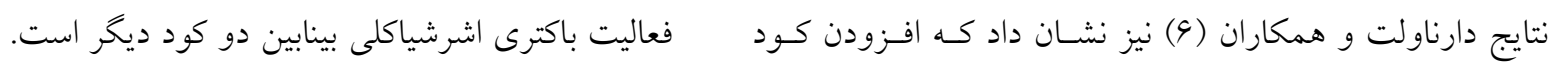

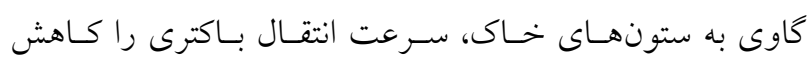
اثر متقابل شورىهاى مختلف آب آبيارى و كود بـر غلظــت باكترى اشرشياكلى در زهآب خروجى مختى

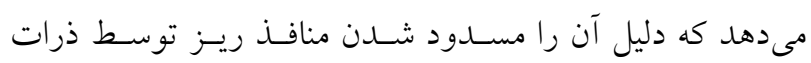
كلوييدى و آلى كود دانستند. همجنين در كود كاوى مقادي مادير زياد

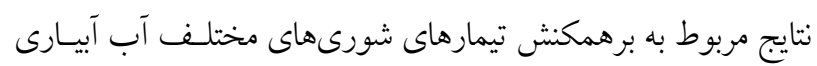

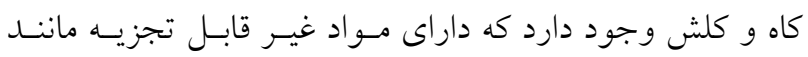

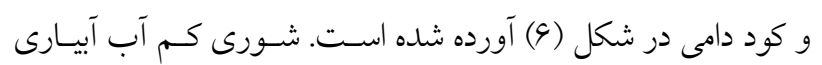

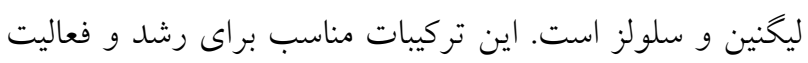




\begin{tabular}{|c|c|c|c|}
\hline $\mathrm{F}$ & 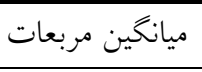 & 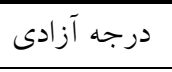 & منابع تغيير \\
\hline \multirow[t]{3}{*}{$V / 99^{* *}$} & r/ATQ & r & 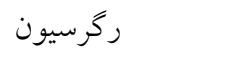 \\
\hline & $0 / 49 V$ & M & باقيمانده \\
\hline & & r & كل \\
\hline \multirow{2}{*}{\multicolumn{4}{|c|}{ 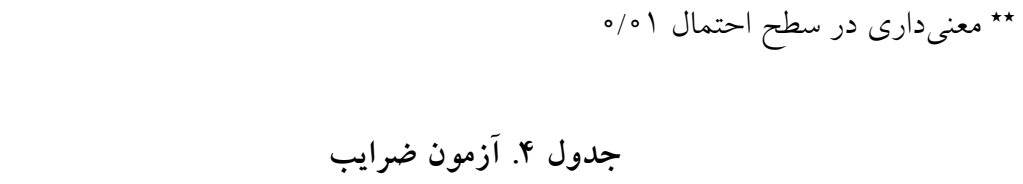 }} \\
\hline & & & \\
\hline $\mathrm{t}$ & \multicolumn{2}{|c|}{$\beta \pm$ std } & 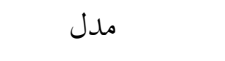 \\
\hline$\circ / \Lambda \circ Y$ & \multicolumn{2}{|c|}{$1 / Y 11 \pm 1 / 01$} & مقدار ثابت \\
\hline$-r / \Delta V \Lambda^{\star *}$ & \multicolumn{2}{|c|}{$-\circ / 190 \pm \circ / \circ \Delta r$} & EC \\
\hline Y/TY * & \multicolumn{2}{|c|}{$\circ / \mathbb{E V} \pm / T Y I$} & $\mathrm{pH}$ \\
\hline \multicolumn{3}{|c|}{ Log Concentration $=1.211-0.195 \mathrm{EC}+0.470 \mathrm{pH}$} & مدل \\
\hline
\end{tabular}

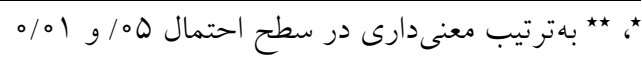

كاوى است و از آنجايى كـه شـدت كـاهش در كـود مرغسى در شورى زياد قابل ملاحظه بود، شايد بتوان اين كـاهش جمعيـت باكترى در كود مخلوط را به كاهش جمعيت باكترىهاى موجود در كود مرغى نسبت داد. جدول تجزيه واريانس موارد ذكر شده در جدول (Y) آورده شده است.

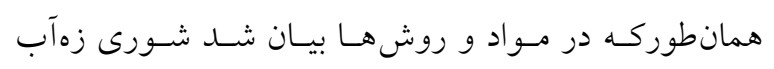

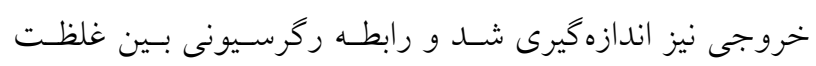

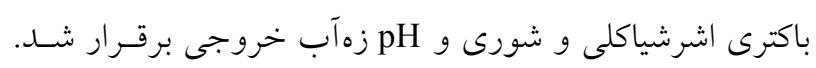

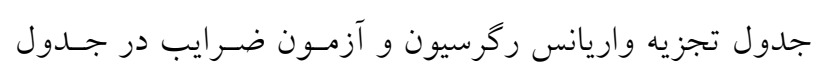

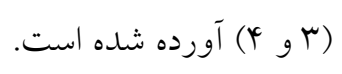

\section{نتيجه كيرى}

شورى آب آبيارى يكى از عوامل مهمى است كه مىتواند منجـر به جذب و پِالايش بـاكترى اشرشـياكلى در خـاك شـود. نتـايج بهدست آمله نشان داد كه شـورى بـهـهـور معنسى دارى موجسبـ كاهش غلظت باكترى در زهآب شد، همجنين كودهاى مختلـف نيز اثر متفاوتى بر غلظت باكترى اشرشـياكلى داشـتند. بيشـترين غلظت باكترى در تيمار كود مرغى و كمتـرين غلظــت در تيمـار
يعنى شورى ه/ ه دسىزيمنس بر متر، تنهـا بـر غلظـت بـاكترى

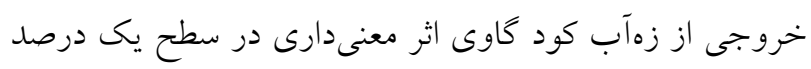

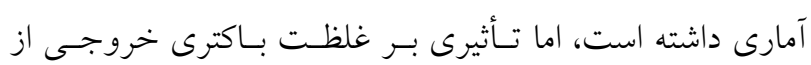

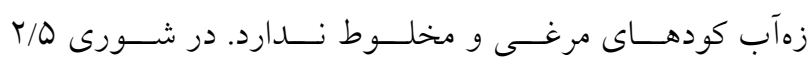
دسىزيمنس بر متر كه شورى متوسط در اين آزمايش محسـوب مىشود، بين هر سه تيمار كودى، اختلاف معنسىدارى در سـطح

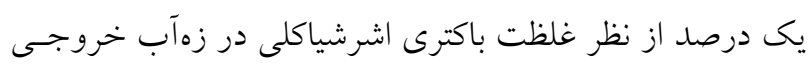
وجود داشت، اما همانطوركه در شكل هم مشخص اسـت، اتـر شورى كم و متوسط بر غلظت بـاكترى خروجسى از زهآب كـود مرغى معنى دار نبود. شايد دليل اين امر بالا بودن قابليت هدايت

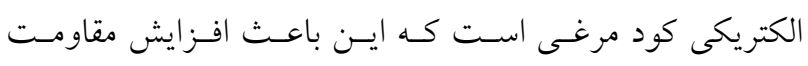

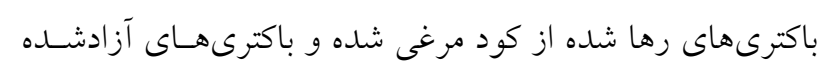

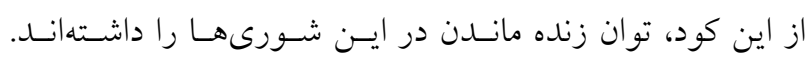
شورى شش دسىزيمنس بـر متـر، بـر كـاهش غلظـت بـاكترى خروجى از هر سه نوع كود بهطور معنى دارى اثـر داثـته اسـت. در اين شورى غلظت باكترىهـاى موجـود در كـود مرغسى نيـز بهطور جشمخيرى كاهش يافـت. در كـود مخلـوط نيـز شـدت كاهش قابل ملاحظه بود. اين كود مخلوطى از دو كود مرغى و 


$$
\begin{aligned}
& \text { كود كاوى ديده شد، همجنين رابطه رگرسيونى كه بـين غلظـت آب آبيارى داشت و با افزايش شورى، غلظـت بـاكترى كـاهش }
\end{aligned}
$$

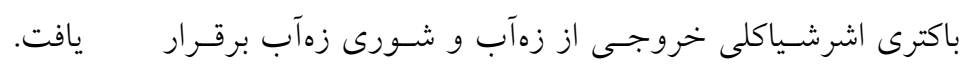

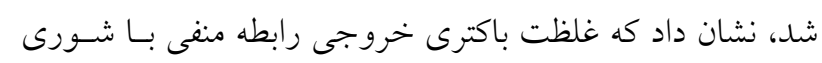

$$
\text { منابع مورد استفاده } 1 .
$$

2. Bitton, G. and R. W. Harvey. 1992. Transport of pathogens through soils and aquifers. PP: 103-124. In: R. Mitchell, (Ed.) Environmental Microbiology. Wiley-Liss, New York.

3. Bradford, S. A., Y. F. Tadassa and Y. Jin. 2006. Transport of coliphage in the presence and absence of manure suspension. Journal of Environmental Quality 35(3): 1692-1701.

4. Bradford, S. A., V. L. Morales, W. Zhang, R. W. Harvey, A. I. Packman, A. Mohanram and C. Welty. 2013. Transport and fate of microbial pathogens in agricultural settings. Critical Reviews in Environmental Science and Technology 43(8): 775-893.

5. Crane, S. R., P. W. Westerman and M. R. Overcash. 1981. Dieoff of fecal indicator organisms following land application of poultry manure. Journal of Environmental Quality 9(1): 531- 537.

6. Darnault, C. J. G., T. S. Steenhuis, P. Garnier, Y. J. Kim, M. B. Jenkins, W. C. Ghiorse, P. C. Baveye and J. Y. Parlange. 2004. Preferntiol flow and transport of cryptosporidium parvum Oocysts through the vadose zone. Vadose Zone Journal 3(1): 262-270.

7. Entry, J. A., R. K. Hubbard, J. E. Theis and J. J. Fuhrmann. 2000. Coliform bacteria: II. Survival in soils. Journal of Environmental Quality 29(3): 1215-1224.

8. Farhangi, M. B., M. R. Mosaddeghi, A. A. Safari-Sinegani and A. A. Mahboubi. 2011. Unsaturated Transport of Cow Manure-Borne Escherichia Coli through the field soil Journal of Water and Soil Science 16(59):127-140.

9. Faust, M. A. 1982. Relationship between land-use practices and fecal bacteria in soils. Journal of Environmental Quality 11(1): 141-146.

10. Filip, Z., D. Kaddu-Mulindwa and G. Milde. 1988. Survival of some pathogenic and facultative pathogenic bacteria in groundwater. Water Science and Technology 20(2): 227-231.

11. Gerba, C. P., C. Wallis and J. L. Melnick. 1975. Fate of wastewater bacteria and viruses in soil. Journal of Irrigation and Drainage Engineering 101(13): 157-174.

12. Gargiulo, G., S. A. Bradford, J. Simunek, P. Ustohal, H. Vereecken and E. Klumpp. 2008. Bacteria Transport and Deposition on under Unsaturated Flow Conditions: The Role of Water Content and Bacteria Surface Hydrophobicity. Vadose Zone Journal 7: 406-419.

13. Hagedorn, C. and E. L. McCoy. 1979. Soil suitability for on-site waste disposal: Development of genetically marked Escherichia coli strains as tracers of subsurface water flow. Water Resources Research Institute. Oregon State University, Corvallis.

14. Hagedorn, C., D. T. Hansen and G. H. Simonson. 1978. Survival and movement of fecal indicator bacteria in soil under conditions of saturated flow. Journal of Environmental Quality 7(1):55-59.

15. Hardie, M. A., W. E. Cotching, R. B. Doyle, G. Holz, S. Lisson and K. Mattern. 2011. Effect of antecedent soil moisture on preferential flow in a texture-contrast soil. Journal of Hydrology 398(3): 191-201.

16. Jewet, D. G., T. A. Hilbert, B. E. Logan, R. G. Arnold and R. C. Bales. 1995. Bacterial transport in laboratory columns and filters: influence of ionic strength and $\mathrm{pH}$ on collision efficiency. Water Research 29(2):1673-1680.

17. Kibbey, H. J., C. Hagedorn and E. L. McCoy. 1978. Use of fecal streptococci as indicators of pollution in soil. Applied and Environmental Microbiology 35(3): 711-717.

18. Kudva, I. T., K. Blanch and C. J. Hovde. 1998. Analysis of Escherichia coli O157:H7 in ovine or bovine manure and manure slurry. Applied and Environmental Microbiology 64(4): 3166-3174.

19. Lang N. L, S. R. Smith. 2007. Influence of soil type, moisture content and biosolids application on the fate of Escherichia coli in agricultural soil under controlled laboratory conditions. Journal of Applied Microbiology 103(14): 2122-2131.

20. Lindqvist, R. and G. Bengtsson. 1995. Diffusion-limited and chemical-interaction-dependent sorption of soil bacteria and microspheres. Soil Biology and Biochemistry 27(3): 941-948.

21. McMurry, S. W., M. S. Coyne and E. Perfect. 1998. Fecal coliform transport through intact soil blocks amended 
with poultry manure. Journal of Environmental Quality 27(5):86- 92.

22. Mosaddeghi, M. R., A. A. Mahboubi, S. Zandsalimi and A. Unc. 2008. Influence of organic waste type and soil structure on the bacterial filtration rates in unsaturated intact soil columns. Journal of Environmental Management 90(12): 730-739.

23. Mubiru, D. N., M. S. Coyne and J. H. Grove. 2000. Mortality of Escherichia coli O157:H7 in two soils with different physical and chemical properties. Journal of Environmental Quality 29(11): 1821-1825.

24. Nicholson, F. A., S. J. Groves and B. J. Chambers. 2005. Pathogen survival during livestock manure storage and following land application. Bioresource Technology 96(11): 135-143.

25. Nodar, R., M. J. Acea and T. Carballas. 1992. Poultry slurry microbial population: composition and evolution during storage. Bioresource Technology 40(4):29-34.

26. Park, S. and K. Song-Bae. 2009. Adhesion of Escherichia coli to iron-coated sand in the presence of humic acid: a column experiment. Water Environment Research 81(14): 125-130.

27. P.Brennan, F., V. O’Flaherty, G. Kramers, J. Grant and G. K. Richards. 2010. Long-Term Persistence and Leaching of Escherichia coli in Temperate Maritime Soil. Applied and Environmental Microbiology 76(5): 1449-1455.

28. Patni, N. K., H. R. Toxepeus and P. Y. Jui. 1985. Bacterial quality of runoff from manured and non-manured cropland. Transactions of the ASAE 28(4):1871-1877.

29. Rahimie, M. K. 2005. Essentials of Medical Microbiology. $1^{\text {nd }}$ (Ed.). Aibig Press. Iran. (In Farsi).

30. Reddy, K. R., R. Khaleel and M. R. Overcash. 1981. Behavior and transport of microbial pathogens and indicator organisms in soils treated with organic wastes. Journal of Environmental Quality 10(1): 255-266.

31. Sepehrnia, N., A. A., Mahboubi, M. R. Mosaddeghi, A. Safari-Sinejani and G. Khodakaramian. 2014. Escherichia coli transport through intact gypsiferous and calcareous soils during saturated and unsaturated flows. Geoderma 217(15): 83-89.

32. Sepehrnia, N., L. Memarianfard, A .A. Moosavi, J. Bachmann, G. Guggenberger, F. Rezanezhad. 2017. Bacterial mobilization and transport through manure enriched soils: Experiment and modeling. Journal of Environmental Management 201: 388-396.

33. Shang, J., M. Flury and Y. Deng. 2009. Force measurements between particles and the air-water interface: implications for particle mobilization in unsaturated porous media. Water Resource Research 45(6): 64-69.

34. Shrestha, S., R. S. Kanwar, C. Cambardella, T. B. Moorman, T. E. Loynachan. 1997. Effect of Swine Manure Application on Nitrogen and Bacterial Leaching through Repacked Soil Columns. ASAE Paper No. 97-2164. St. Joseph, MI: Paper American Society of Agricultural Engineers (972164): 20 pp.

35. Stocker, M. D., Y. A. Pachepsky, R. L. Hill and D. R. Shelton. 2015. Depth dependent survival of Escherichia coli and enterococci in soil after manure application and simulated rainfall. Applied and Environmental Microbiology 81(14): 4801-4808.

36. Tate, R. L. 1978. Cultural and environmental factors affecting the longevity of Escherichia coli in histosols. Applied and Environmental Microbiology 35(3): 925-929.

37. Torsvika, V., J. Gohsoyr, F. L. Daae. 1990. High diversity in DNA of soil bacteria. Applied and Environmental Microbiology 56(50): 782-807.

38. Vasiliki, I. S. and C. V. Chrysikopoulos. 2011. Transport of biocolloids in water saturated columns packed with sand: Effect of grain size and pore water velocity. Journal of Contaminant Hydrology 126(11): 301-314.

39. Vergine, P., R. Saliba, C. Salerno, G. Laera, G. Berardi, and A. Pollice. 2015. Fate of the fecal indicator Escherichia coli in irrigation with partially treated wastewater. Water Research 85(2): 66-73. 


\title{
The Effect of Salinity of Water Irrigation and Manure on Leaching Escherchia coli in Disturbed Soil Columns
}

\author{
H. Shirani ${ }^{1 *}$ S. Shirvani ${ }^{1}$ and M. Moradi ${ }^{2}$
}

(Received: January 27-2017 ; Accepted: September 23-2017)

\begin{abstract}
In recent years, microbial contamination of surface and groundwater is a serious problem in some countries, leading to dangerous diseases. Soil salinity and irrigation water can affect the amount of transport or survival of bacteria in soil. In this study, the effect of different levels of salinity of irrigation water with EC: $0.5,2.5,6 \mathrm{ds} / \mathrm{m}$ and three manures including poultry manure, cow manure and the mixture of poultry and cow manure with 10 ton ha ${ }^{-1}$ on the transport of Escherchia coli was investigated in disturbed soil columns with $30 \mathrm{~cm}$ height and $10 \mathrm{~cm}$ diameter under unsteady-state water conditions. The concentration of Escherchia coli was measured. The severity of the effluent contamination of the treated columns with water salinity was $6 \mathrm{ds} / \mathrm{m}$, which was less than that with the salinity of 2.5 and $0.5 \mathrm{ds} / \mathrm{m}$. This difference was significant at the 0.01 probability level. Also, the effluent contamination of poultry manure-treated columns was greater than the cow manure and the mixed manure, and the contamination of mixed manure was greater than that of cow manure. The interaction of different salinity treatments on the concentration of Escherchia coli in different fertilizer treatments was significant at the 0.01 probability level. The results showed that the concentration of the released bacteria was affected by irrigation water salinity and with increasing the salinity, the concentration of the bacteria was reduced.
\end{abstract}

Keywords: Breakthrough curve, Poultry manure, Cow manure, Effluent contamination

1. Department of Soil Science, Faculty of Agriculture, Vali-e-Asr University of Rafsanjan, Rafsanjan, Iran.

2. Department of Virology and Microbiology, Faculty of Medicine, Medical Science University of Kerman, Kerman, Iran.

*: Corresponding Author, Email: e-mail:shirani@vru.ac.ir 